\title{
Breast meat quality of broilers fed fermented red ginseng marc powder mixed with red-koji during storage
}

\author{
S. C. Kim¹, G. D. Lee ${ }^{2}$, I. H. Choi ${ }^{3 *}$ \\ ${ }^{1}$ Division of Applied Life Science (BK21Plus, Insti. of Agri. \& Life Sci.), Gyeongsang National University, Jinju, South Korea, ${ }^{2}$ Department of \\ Food Science and Biotechnology, Joongbu University, Geumsan-gun, South Korea, ${ }^{3}$ Department of Companion Animal \& Animal Resources \\ Science, Joongbu University, Geumsan-gun, South Korea
}

\section{A B S T R A C T}

\begin{abstract}
The breast meat quality of broilers fed four different types of red ginseng marc (DTRG) during storage at $4{ }^{\circ} \mathrm{C}$ was investigated in this study. The experiment had a completely randomized design with four groups and four replicates; 240 Arbor Acres broiler chicks (160 males and 80 females) were used. The groups consisted of the control, $2 \%$ red ginseng marc, $1 \%$ fermented red ginseng marc with red-koji, and $2 \%$ liquid red ginseng. No remarkable effects on $\mathrm{pH}$ values of breast meat were observed in groups fed DTRG during storage (but not the group fed $1 \%$ fermented red ginseng combined with red-koji). Both groups and storage had a significant effect $(p<0.05)$ on lightness $\left(L^{*}\right)$, redness $\left(a^{*}\right)$, and yellowness $\left(b^{*}\right)$ values (but not $L^{*}$ values at 7 days, $a^{*}$ values at 1 day, and $b^{*}$ values at 7 days or $L^{*}$ values in T3 groups and $a^{*}$ values in T1 groups over storage). 1,1-diphenyl-2-picrylhydrazyl (DPPH) radical-scavenging activity showed significant differences $(p<0.05)$ between groups and storage days. In conclusion, diets supplemented with $1 \%$ fermented red ginseng powder combined with red-koji is helpful in improving DPPH radical-scavenging activity (antioxidant effect) in broiler breast meat, possibly because of the saponins, flavonoids and polyphenols present in red ginseng marc.
\end{abstract}

Keywords: Fermented red ginseng marc powder; Red-koji; Red ginseng marc; Meat color; DPPH radical-scavenging activity

\section{INTRODUCTION}

Ginseng (Panax ginseng Meyer) is a slow-growing perennial plant (4 to 6 years), and it is distributed mainly in Korea, Japan, China, and the Maritime Province of Siberia and usually in subarctic and temperate regions (Choi et al., 2007; Zhuravlev et al., 2008). Ginseng has been used as an herbal medicine for thousands of years (Choi et al., 2011). Recently, many ginseng products to which a functional food or food flavor is added to enhance its effectiveness (health and body vigor) have appeared in the local or global market (Ryu et al., 2012). Ginseng roots can be divided into three types on the basis of the method of processing: fresh ginseng (less than 4 years of age), white ginseng ( $4-6$ years of age; roots are dried after peeling), and red ginseng (Yun, 2001). Red ginseng is harvested when it is 6 years of age, and the roots are dried after steaming in water vapor at $98-100^{\circ} \mathrm{C}$. A previous study revealed that ginseng has saponins, phenolics, polysaccharides, alkaloids, and lignans (Palazon et al., 2003). In addition, a review on the various properties of saponins, which are regarded as important bioactive ingredients, had been published (Francis et al., 2002). Interest in red ginseng has increased in the past two decades as a result of its potential beneficial effects (antioxidant activity and immunostimulatory, antistress, and vasorelaxing effects), as confirmed by Yildirim et al. (2013).

An alternate approach for improving animal diet and meat quality is to use red ginseng marc or red koji prepared by fermentation with species that belong to the genus Monascus. Red ginseng marc is a fibrous and insoluble byproduct obtained after the extraction process of ginseng. It was believed to be a waste product, but studies showed that red ginseng marc powder or fermented red ginseng marc has pharmacological properties and strong antioxidant effects (Jung et al., 2010; Lim et al., 2004). In a study to apply poultry diets (3\%), Kim et al. (2014) reported the potential effects of red ginseng marc on antioxidant activity.

\footnotetext{
${ }^{*}$ Corresponding author:

In Hag Choi, Department of Companion Animal \& Animal Resources Science, Joongbu University, Geumsan-gun, South Korea.

Tel: +82-41-750-6284, E-mail: wicw@chol.com
}

Received: 23 January 2015;

Revised: 27 February 2016;

Accepted: 28 February 2016;

Published Online: 11 March 2016 
Red-koji (Monascus species) has been traditionally used as a medicinal food and a fermentation source for other herbs in East Asia (Kim et al., 2013). For example, a product fermented using Monascus was gradually considered to be a functional food because monacolin $\mathrm{K}$ (anti-hypercholesterolemic agent), $\gamma$-aminobutyric acid (hypotensive agent), and dimerumic acid (antioxidant) were present (Aniya et al., 2000; Su et al., 2003). However, to the best of our knowledge, there are no studies on the effects of fermented red ginseng marc powder combined with red-koji on the meat quality (antioxidative properties) of broilers. It is therefore essential to study the physiological activities and antioxidative properties of fermented red ginseng marc powder combined with red-koji. This study was performed to investigate the breast meat quality of broilers fed fermented red ginseng marc powder mixed with red-koji during hypothermic storage.

\section{MATERIALS AND METHODS}

\section{Birds and experimental design}

Red ginseng marc, fermented red ginseng marc, red-koji, and liquid red ginseng were purchased from Ginseng Organic Co. (Seoul, Korea). Fermented red ginseng marc and redkoji were mixed at a ratio of 9:1. All samples were quickly prepared for the experiments. The animal care protocol used in this study was according to the guidelines of the Dansan Farm (Yeongju, South Korea). A total of 240 broiler chicks (160 males and 80 females, Arbor acres, and 1 day of age) were randomly allotted to one of the following four dietary groups: control (basal diet), T1 (basal diet with 2\% red ginseng marc), T2 (basal diet with $1 \%$ fermented red ginseng marc combined with red-koji), and T3 (basal diet with $2 \%$ liquid red ginseng). The experiment had a completely randomized design with four replicate pens of 10 male and 5 female birds per group. The trial was performed in two phases: a starter phase (day 1 to 21, $12.97 \mathrm{MJ} / \mathrm{kg} \mathrm{ME}$, $22 \%$ crude protein, $6 \%$ crude fat, $7 \%$ crude fiber, $10 \%$ crude ash, $0.9 \% \mathrm{Ca}$, and $1 \% \mathrm{P}$ ) and a finisher phase (day 22 to $28,12.97 \mathrm{MJ} / \mathrm{kg} \mathrm{ME}, 19 \%$ crude protein, $6 \%$ crude fat, $7 \%$ crude fiber, $10 \%$ crude ash, $0.8 \% \mathrm{Ca}$, and $0.9 \% \mathrm{P}$ ). The chicks were reared in an environmentally controlled room in $1.1 \times 1.2-\mathrm{m}$ pens with a tube feeder and a hanging bell drinker. They were maintained on a 24-h light schedule (14-h/10-h light/dark cycle), and feed and water were provided ad libitum throughout the 28-day experimental period. Ambient temperature was maintained at $35^{\circ} \mathrm{C}$ for the first week, after which the temperature was gradually reduced to $24^{\circ} \mathrm{C}$ and maintained during the four-week trials; ventilation was automatically regulated. In the 28 -day trial, the following litter materials were used: wood shavings and rice hulls (an approximately 6 -cm layer). At the end of the feeding trials, the birds were fasted for $6 \mathrm{~h}$. Three birds per pen were randomly selected, moved to the slaughterhouse, and electrically stunned. The birds were killed using a full ventral neck cut and exsanguinated, according to conventional slaughter procedures. Breast meat samples were excised and immediately packed in sealable plastic bags. Meat quality was analyzed during storage at $4^{\circ} \mathrm{C}$ on the postmortem days 1,3 , and 7 .

\section{Measurement of meat quality $p H$}

The $\mathrm{pH}$ of ground meat was determined in triplicate by using the method described by Kim et al. (2014). About $10 \mathrm{~g}$ of ground breast meat was homogenized in $90 \mathrm{~mL}$ of distilled water by using a blender (HM-3000; Hyundai Electronic Industry Co., Incheon, South Korea) for $1 \mathrm{~min}$, and $\mathrm{pH}$ of the homogenate was determined using a digital $\mathrm{pH}$ meter (691 $\mathrm{pH}$ meter; Metrohm, Swiss) calibrated at pH 4.0 and 7.0.

\section{Meat color}

Color values of the breast meat samples were measured using a Minolta colorimeter (Minolta Co. CR 301, Japan) calibrated against a standard white tile (reference number 12633117, $Y=93.5, x=0.3132$, and $y=0.3198)$. Lightness $\left(\mathrm{L}^{*}\right)$, redness $\left(\mathrm{a}^{*}\right)$, and yellowness $\left(\mathrm{b}^{*}\right)$ values were obtained using the average value of three repeated measurements taken from different locations on the surface of the meat samples.

\section{1,1-Diphenyl-2-picrylhydrazyl (DPPH) radical- scavenging assay}

Ability of the samples to scavenge 1,1-diphenyl-2picrylhydrazyl (DPPH) radicals was estimated in triplicate using the aqueous supernatant obtained from breast meat, according to the method of Blois (1958) with slight modifications. Ascorbic acid was used as the standard solution. The extract $(1 \mathrm{~mL})$ was added to $4 \mathrm{~mL}$ of ethanolic DPPH solution $(100 \mu \mathrm{M})$ and vortexed. The mixture was allowed to stand for $30 \mathrm{~min}$ at room temperature, and then absorbance was measured at $517 \mathrm{~nm}$ by using a UV-Vis spectrophotometer (Shimadzu, Japan). The percentage of $\mathrm{DPPH}$ free radical-scavenging activity was calculated using the following equation:

DPPH radical scavenging $(\%)=[1-($ absorbance of sample solution/absorbance of control)] $\times 100$

\section{Statistical analysis}

Data were evaluated using analysis of variance (SAS software; SAS Institute, 2002). For all analyzed data, the pen was used as the experimental unit. Duncan's multiple range test was used at an overall significance level of $\mathrm{P}=0.05$ to make comparisons among mean values (Duncan, 1955). 


\section{RESULTS AND DISCUSSION}

\section{pH and meat color}

The $\mathrm{pH}$ and meat color of the broilers fed diets with DTRG are listed in Table 1. Overall, $\mathrm{pH}$ values in all groups were similar during storage. No remarkable effects of DTRG on $\mathrm{pH}$ values of breast meat were observed in the groups when compared with the control $(p>0.05)$. However, the T2 group showed a minor significant $(p<0.05)$ effect on $\mathrm{pH}$ as the number of storage days increased.

With respect to meat color, an increase and a decrease $(p<0.05)$ in $\mathrm{L}^{*}$ and $\mathrm{a}^{*}$ values were observed in both groups and storage. All groups had a significant effect $(p<0.05)$ on $\mathrm{b}^{*}$ values, which tended to increase with storage days. However, no significant differences in $\mathrm{L}^{*}$ values at 7 days, $a^{*}$ values at 1 day, and $b^{*}$ values at 7 days were found in all groups, including $\mathrm{L}^{*}$ values in T3 groups and $\mathrm{a}^{*}$ values in T1 groups over storage. The highest values of $\mathrm{L}^{*}$ and $\mathrm{b}^{*}$ and the lowest values of $\mathrm{a}^{*}$ were observed in the T2 group (Table 1). Even though our result indicated that meat color was significantly different among groups fed DTRG, it seems that the different types of red ginseng did not have an antioxidant effect on meat color. In particular, fermented or red ginseng marc has been shown to be a biologically active compound with antioxidant effectiveness (Jung et al., 2010). In addition, red-koji is used as a food colorant, flavoring agent, and preservative and widely used for its antioxidant or medicinal properties (Arunachalam and Narmadhapriya, 2011). Nevertheless, our findings did not support those of Fernandez-Lopez et al. (2005), who claimed that using natural extracts applied to beef meatballs during storage had significant advantages. Previous studies have shown that the presence of natural antioxidants could retard the formation of metmyoglobin and have highly suppressive effects and decrease $L^{*}$ or increase $a^{*}$ values (Fernandez-Lopez et al., 2005; Velasco and Williams, 2011). In contrast, Kim et al. (2014) suggested that the color of the thigh muscle was not affected by supplementation of broiler diets with increased levels of red ginseng marc.

In general, meat $\mathrm{pH}$ and color are considered as important criteria that influence antioxidant effectiveness and consumer preference. In the current study, $\mathrm{pH}$ values in the groups with DTRG were not the determining factor for breast meat color. According to Xiong et al. (1993), improvement in meat quality may be partially due to the fact that the effectiveness of an antioxidant agents such as polyphenols or flavonoids is based on $\mathrm{pH}$; however, phenolic compounds do not always respond to a reduction in $\mathrm{pH}$. Currently, the mechanism underlying this difference between $\mathrm{pH}$ and meat color for the different types of red ginseng is still unclear.

\section{DPPH radical-scavenging assay}

$\mathrm{DPPH}$ radical-scavenging activity showed significant differences $(p<0.05)$ between all groups and storage days (Fig. 1). In the present study, DPPH radical-scavenging activity was observed in the following order: T2 $>$ T1 $>$ T3 $>$ Control. This result implies that the combination of fermented red ginseng marc and red-koji or red

Table 1: Effect of the addition of fermented red ginseng marc with red-koji to poultry diets on pH and meat color of breast muscle of broiler during storage at $4^{\circ} \mathrm{C}$

\begin{tabular}{|c|c|c|c|c|}
\hline \multirow[t]{2}{*}{ Item } & \multirow[t]{2}{*}{ Treatments $^{1}$} & \multicolumn{3}{|c|}{ Storage day } \\
\hline & & 1 & 3 & 7 \\
\hline \multirow[t]{4}{*}{$\mathrm{pH}$} & $C$ & $5.97 \pm 0.15^{\mathrm{aA}}$ & $6.09 \pm 0.21^{\mathrm{aA}}$ & $6.07 \pm 0.17^{\mathrm{aA}}$ \\
\hline & $\mathrm{T} 1$ & $6.16 \pm 0.14^{\mathrm{aA}}$ & $6.10 \pm 0.15^{\mathrm{aA}}$ & $6.00 \pm 0.17^{\mathrm{aA}}$ \\
\hline & $\mathrm{T} 2$ & $6.04 \pm 0.08^{\mathrm{aA}}$ & $5.89 \pm 0.15^{\mathrm{aB}}$ & $6.01 \pm 0.10^{\mathrm{aAB}}$ \\
\hline & T3 & $6.04 \pm 0.14^{\mathrm{aA}}$ & $6.12 \pm 0.12^{\mathrm{aA}}$ & $6.09 \pm 0.04^{\mathrm{aA}}$ \\
\hline \multicolumn{5}{|l|}{ Meat color } \\
\hline \multirow[t]{4}{*}{ L (lightness) } & C & $50.96 \pm 2.78^{\mathrm{aAB}}$ & $48.65 \pm 5.55^{\mathrm{bB}}$ & $51.49 \pm 3.37^{a A}$ \\
\hline & $\mathrm{T} 1$ & $48.34 \pm 4.39^{\mathrm{bB}}$ & $50.79 \pm 4.28^{\mathrm{bAB}}$ & $51.76 \pm 4.10^{\mathrm{aA}}$ \\
\hline & $\mathrm{T} 2$ & $48.99 \pm 2.33^{b c}$ & $54.58 \pm 2.95^{\mathrm{aA}}$ & $52.47 \pm 3.10^{\mathrm{aB}}$ \\
\hline & T3 & $49.73 \pm 2.58^{\mathrm{abA}}$ & $50.05 \pm 3.87^{\mathrm{bA}}$ & $51.71 \pm 2.80^{\mathrm{aA}}$ \\
\hline \multirow[t]{4}{*}{$\mathrm{a}^{*}$ (redness) } & $\mathrm{C}$ & $5.58 \pm 1.49^{\mathrm{aB}}$ & $6.33 \pm 1.08^{\mathrm{bA}}$ & $5.49 \pm 1.16^{\mathrm{abB}}$ \\
\hline & T1 & $6.40 \pm 1.67^{\mathrm{aA}}$ & $6.74 \pm 1.53^{\mathrm{abA}}$ & $6.14 \pm 1.48^{\mathrm{aA}}$ \\
\hline & T2 & $5.80 \pm 1.21^{\mathrm{aA}}$ & $5.06 \pm 1.00^{\mathrm{cB}}$ & $4.73 \pm 1.52^{\mathrm{bB}}$ \\
\hline & T3 & $5.98 \pm 1.17^{\mathrm{aB}}$ & $7.17 \pm 0.96^{\mathrm{aA}}$ & $5.01 \pm 0.74^{\mathrm{bC}}$ \\
\hline \multirow[t]{4}{*}{$b^{*}$ (yellowness) } & C & $6.61 \pm 1.91^{\mathrm{bB}}$ & $7.34 \pm 1.02^{\mathrm{cB}}$ & $9.66 \pm 2.32^{\mathrm{aA}}$ \\
\hline & T1 & $6.41 \pm 1.49^{\mathrm{bB}}$ & $7.23 \pm 1.15^{\mathrm{cB}}$ & $8.99 \pm 3.18^{\mathrm{aA}}$ \\
\hline & T2 & $7.51 \pm 1.19^{a B}$ & $10.77 \pm 3.17^{\mathrm{aA}}$ & $10.74 \pm 3.14^{\mathrm{aA}}$ \\
\hline & T3 & $7.69 \pm 0.88^{\mathrm{aB}}$ & $8.84 \pm 2.14^{\mathrm{bAB}}$ & $10.00 \pm 2.29^{a A}$ \\
\hline
\end{tabular}

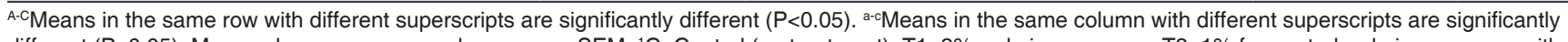
different $(\mathrm{P}<0.05)$. Mean values are expressed as means $\pm \mathrm{SEM} .{ }^{1} \mathrm{C}=\mathrm{Control}$ (no treatment); $\mathrm{T} 1=2 \%$ red ginseng marc; $\mathrm{T} 2=1 \%$ fermented red ginseng marc with red-koji; T3=2\% liquid red ginseng 


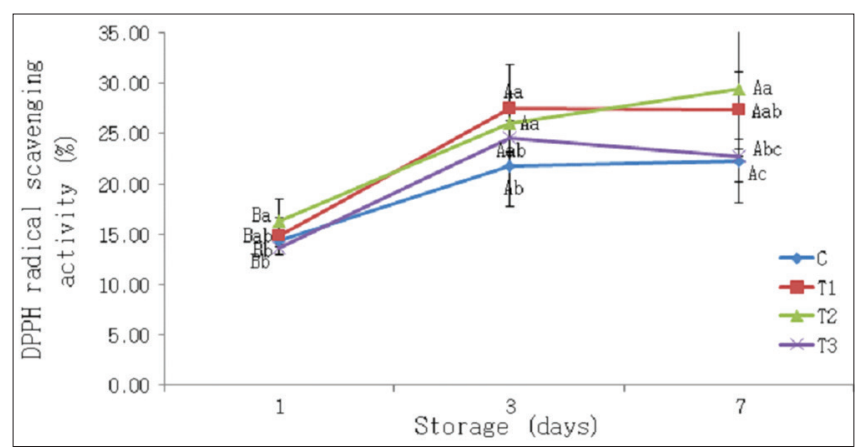

Fig 1. Effect of the addition of fermented red ginseng marc with red koji to poultry diets on DPPH radical scavenging of breast muscle of broiler during storage at $4^{\circ} \mathrm{C}$. A-B (row) and a-c (colomn) Bars with same letters are not significantly different at $P<0.05$. Treatments means $\mathrm{C}=\mathrm{Control}$ (no treatment); $\mathrm{T} 1=2 \%$ red ginseng marc; $\mathrm{T} 2=1 \%$ fermented red ginseng marc with red-koji; T3 $=2 \%$ liquid red ginseng

ginseng marc may be important for improving antioxidant properties during storage. In other words, an increase in DPPH radical-scavenging activity has a positive impact on meat quality, possibly because of the saponins present in red ginseng marc and the ability to serve as efficient free-radical scavengers (Kim et al., 2014). Kim et al. (2014) showed that DPPH radical-scavenging activity in thigh meat increased significantly with increasing levels of red ginseng marc.

\section{CONCLUSION}

Our findings revealed that the antioxidant potential of DPPH radical-scavenging activity in broiler breast meat can be improved by supplementation with different types of red ginseng. DPPH radical-scavenging activity was higher in the group fed 1\% fermented red ginseng marc combined with red- koji. However, no remarkable effects on $\mathrm{pH}$ values and meat color of breast meat were observed in the groups during storage. Furthermore, $\mathrm{pH}$ values in the groups fed DTRG were not the determining factor for breast meat quality.

\section{ACKNOWLEDGEMENTS}

The authors are grateful to the Small and Medium Business Administration funded by the Korean Government (grant No. C0150527) for their support to carry out this research.

\section{Authors' Contributions}

Sam Churl Kim and Gee Dong Lee contributed equally to this work in chemical analyzes and review for the manuscript as first author. In Hag Choi designed and performed research, wrote and revised the manuscript. All authors have read and approved the final version of the paper.

\section{REFERENCES}

Aniya, Y., II. Ohtani, T. Higa, C. Miyagi, H. Gibo, M. Shimabukuro, H. Nakanish and J. Taira. 2000. Dimerumic acid as an antioxidant of the mold, Monascus anka. Free Radic. Biol. Med. 286(6): 999-1004.

Arunachalam, C. and D. Narmadhapriya. 2011. Monascus fermented rice and its beneficial aspects: A new review. Asian J. Pharm. Clin. Res. 1: 29-31.

Blois, M.S. 1958. Antioxidant determination by the use of a stable free radical. Nature. 181(4617): 1199-2000.

Choi, S.Y., H.D. Hong, H.M. Bae, C. Choi and K.T. Kim. 2011. Phytochemical characteristics of coffee bean treated by coating of ginseng extract. J. Ginseng. Res. 35(4): 436-441.

Choi, Y.E., Y.S. Kim, M.J. Yi, W.G. Park, J.S. Yi, S.R. Chun, S.S. Han and S.J. Lee. 2007. Physiological and chemical characteristics of field and mountain cultivated ginseng roots. J. Plant Biol. 50(2): 198-205.

Duncan, D.B. 1955. Multiple range and multiple F-test. Biometrics. 11: $1-42$.

Fernandez-Lopez, J., N. Zhi, L. Aleson-Carbonell, J.A. Perez-Alvarez and V. Kuri. 2005. Antioxidant and antibacterial activities of natural extracts: Application in beef meatballs. Meat Sci. 69(3): 371-380.

Francis, G., Z. Kerem, H.P.S. Makkar and K. Becker. 2002. The biological action of saponins in animal system: A review. Br. J. Nutr. 88(6): 587-605.

Jung, H.W., J.E. Kim, J.H. Seo and S.P. Lee. 2010. Physicochemical and antioxidant properties of red ginseng marc fermented by Bacillus subtilis HA with Mugwort powder addition. J. Korean Soc. Food Sci. Nutr. 39(9): 1391-1398.

Kim, C.M., S.J. Yi, I.J. Cho and S.K. Ku. 2013. Red-Koji fermented red ginseng ameliorates high fat diet-induced metabolic disorders in mice. Nutrients. 5(11): 4316-4332.

Kim, Y.J., G.D. Lee and I.H. Choi. 2014. Effects of dietary supplementation of red ginseng marc and $\alpha$-tocopherol on the growth performance and meat quality of broiler chicken. J. Sci Food. Agric. 94(9): 1816-1821.

Lim, T.S., K. Na, E.M. Choi, J.Y. Chung and J.K. Hwang. 2004. Immunomodulating activities of polysaccharides isolated from Panax ginseng. J. Med. Food. 7(1): 1-6.

Palazon, J., R.M. Cusido, M. Bonfil, A. Mallol, E. Moyamo, C. Marales and M.T. Pinol. 2003. Elicitation of different Panax ginseng transformed root phenotypes for an improvement ginsenoside production. Plant Physiol. Biochem. 41(11-12): 1019-1025.

Ryu, K.R., M.H. Yeom, S.S. Kwon, H.S, Rho, D.H. Kim, H.K. Kim and K.W. Yun. 2012. Influence of air temperature on the histological characteristics of ginseng (Panax ginseng C. A. Meyer) in six regions of Korea. Aust. J. Crop Sci. 6(12): 1637-1641.

SAS Institute. 2002. SAS/STAT User's Guide: Version 8.2. SAS Institute, Cary, NC.

Su, Y.C., J.J. Wang, T.T. Lin and T.M. Pan. 2003. Production of the secondary metabolites $\mathrm{Y}$-aminobutyric acid and monacolin $\mathrm{K}$ by Monascus. J. Ind. Microbiol. Biotechnol. 30(1): 40-46.

Velasco, V. and P. Williams. 2011. Review: Improving meat quality through natural antioxidants. Chilean. J. Agric. Res. 71(2): 313-322.

Xiong, Y.L., E.A. Decker, G.H. Robe and W.G. Moody. 1993. Gelation of crude myofibrillar protein isolated from beef heart under antioxidative conditions. J. Food Sci. 58(6): 1241-1244. 
Yildirim. A., A. Şekeroglu, H. Eleroglu, M.I. Şen and M. Duman. 2013. Effects of Korean (Panax ginseng C.A. Meyer) root extract on egg production performance and egg quality of laying hens. S. Afr. J. Anim Sci. 43(2): 194-207.

Yun, T.K. 2001. Panax ginseng - A non-organ-specific cancer preventive? Lancet Oncol. 2(1): 49-55.

Zhuravlev, Y.N., O.G. Koren, G.D. Reunova, T.I. Muzarok, T.Y. Gorpenchenko, I.L. Kats and Y.A. Khrolenko. 2008. Panax ginseng natural populations: Their past, current state and perspectives. Acta Pharmacol. Sin. 29(9): 1127-1136. 